\title{
Conservation of biodiversity through scientifically validated and well participated people's biodiversity registers (PBRS) in Goa, India
}

\author{
Ranjita U. Sawaiker \\ Department of Botany, PES's RSN College of Arts and Science,Farmagudi, Ponda Goa,403401, India
}

(Received: November 05, 2020; Revised: December, 2020; Accepted: January 26, 2021)

\begin{abstract}
Traditional Knowledge possessed by indigenous communities is acquired through generations. Goa has 197 urban and rural local bodies and has constituted Biodiversity Management Committees as per guidance of Goa State Biodiversity Board. Documentation of native biodiversity and bioresources in PBRs involves local people and Technical Support Groups. Biodiversity Management Committee documents the resources of village, histo - socio - cultural and natural habitats that has rare, endangered plants, ecological habitat versatility likelakes, springs, management technology of regulating the Khazan lands, agro-pisci ecological systems, age old unique hydrogeological set up created by local techniques for surface water management.PBR'S are validated by three tier validation system i.e. Biodiversity Management Committee, Village Panchayats in Gram Sabhas and Thematic Expert Committee for PBR Validation constituted by Goa State Biodiversity Board. This is unique participative process in world that involves scientific validation of systematic documentation carried out by the owners of bioresources. The paper discusses a case study of Curtorim village of Goa where local people have documented the bioresources. The outcome of PBR validation process has resulted in declaration of flagship species in villages, promotion of traditionally grown rice varieties by giving brand name with the initiative of Goa State Biodiversity Board, reviving the age old cultures etc.
\end{abstract}

Keywords: People Biodiversity Register, Khazan lands, Agro-pisci ecosystem, Biodiversity management committee, Technical support groups

\section{INTRODUCTION}

Biological diversity contributes to security, resiliency, and freedom of choices and actions (Reid and Mooney 2005). Wild lands continue to suffer widespread incursions from agricultural expansion, urbanization, and industrial development, overexploitation threatens the viability of wild populations, invasive species wreak havoc on ecosystems (Vitouseket al. 1997; Wake and Vredenburg 2008).In many respects, conservation of biological diversity is local, as people depend upon it the most. India is one of the 17 mega bio diverse countries rich in biodiversity wherein associated Traditional Knowledge is predominantly possessed by indigenous local communities and acquired through generations of empirical research.

\section{Biodiversity documentation by People's Biodiversity Register (PBR)}

According to Rautaray et al., (2014) PBR is a unique program in tune with the objectives of the convention on biological diversity to respect, preserve and maintain the knowledge. This comprises of the Peoplescape: Different segments of concerned human communities and their relationship to the local base of natural, living resources. Landscape: The local mosaic of different kinds of land and water habitats from over which the concerned people bring in most of living resources. Mindscape/ Socialscape: Information available with people dealing with living resources as a part of their daily subsistence activities like grazers, fisher folk, basket weavers, hunters, farmers, healers, local villagers etc. who are nevertheless specialists of science. PBR process involves distinct set of actors like local people, Village panchayat assisted by technical support group and Goa State Biodiversity Board. During PBR documentation the information is gathered from local people, existing records, from departments like agriculture, animal husbandry, fisheries, forestry, horticulture etc. There is involvement of educational and scientific institutions, State and District Councils of Science and Technology, centers of Natural Resource Data Management System, etc.

Objective of the PBR is to systematically record, organize, document, create records by wayof notes, audio - video clips and secure available information related to uses, characteristics, conservation, preservation, propagation and management of the living resources in detail. The PBR format is divided into three parts i.e., Part I comprising of General description about the Gram Panchayat (GP) with GPS location (Annexure 1-4); Maps (GP, Taluk \& Zilla /District); Photos- field study, training to BMC/ TSG members and diversity of the Gram Panchayat. Part II are Formats 1-30(related to agro biodiversity, peoples scape, waterscape, medicinal plants, ornamentals, timber yielding plats, fishery techniques, wild/domesticated animals etc.) where as Part III includes Profile of the study area, details of the natural resources, abbreviations,(http:// www.mpsbb.nic.in/pbr/PBR\%20Manual\%20and\%20Format\% 20-\%20English.pdf). After collection and verification the information is made available to the society at large but

*Corresponding Author's E-mail: ranjitasawaikar@gmail.com 
the sensitive, unique and any other information which can lead to commercialization is treated as confidential as per the prevailing legal provisions. PBR thus embrace the creation of decentralized databases. Three copies are made and kept with BMC, GSBB and National Biodiversity Authority of India (NBA)

\section{METHODOLOGY}

\section{PBR Documentation process in Goa}

In the state of Goa there are total 205 local and urban local bodies and out of which 197 bodies have constituted biodiversity management committees (BMCs) constituted by local body as per the guidance of Goa State Biodiversity Board https://gsbb.goa.gov.in/ Sensitization of villagers is done before the entire process of PBR preparation. Further BMC takes up documentation of native biodiversity in PBRs by involving local people and with assistance of Technical Support Groups (TSG - group of experts in biodiversity \& related fields selected by GSBB). These PBRs are validated by three tier validation system i.e. Biodiversity Management Committee, the Village Panchayats in Gram Sabhas and the Thematic Expert Committee(TEC) for PBR Validation constituted by Goa State Biodiversity Board. Thereafter during final validation, conservation priorities and focus areas are decided based on which specific programs are taken up in the villages. This process is unique in the world thus the biological diversity along with Traditional Knowledge, festivals, rituals, traditional practices, flora/ fauna, sacred grooves, are not only scientifically documented by native people but also conservation steps are taken. Primary data was collected by conducting Transect Walk, Interview/audio/video recordings of local people, Photography whereas secondary data was collected using books, journals, magazines and newspapers.

Case study of Cutorim village as documentated by Biodiversity Management Comittee of Curtorim

The area of Curtorim is appx. 1,735.5 Ha with approximate length of $4.5 \mathrm{kms}$ and breadth of $4 \mathrm{kms}$. Area under agriculture is nearly $65 \%$ with irrigated land occupying $386 \mathrm{Ha}$, unirrigated land being $699 \mathrm{Ha}$ and waste land 25 Ha. About $53 \%$ of Agricultural land is held by owners, $45 \%$ COMUNIDADE(a legal entity that owns all land in a village that is not privately owned nd $2 \%$ being Institutional (Fernandes, 2016). The village can be broadly divided into two physiographic divisions'i.e. isolated hillocks and riverine plains along river Zuari which lies below the contour interval of 20 meters. The village displays communal harmony. People of the village celebrate 'Khandikhuris feast'annually on August $20^{\text {th }}$. The significance of this feast is that from this day, the villagers commence preparation of building the Khandi (Sluice gate) that blocks the water from entering the nearby fields and also stores the water for the post monsoon rabi crops. This feast has been celebrated in the village by Xetkars (Farmers) since centuries (Azavedo, 2015).Harvest Festival (Novidade) -The Harvest Thanks giving Day, August $15^{\text {th }}$ is one of rejoicing event for the catholic farmers of Curtorim (Rubinoff 2001). Traditional knowledge inherited by the communities and the socialscapesin this village are exemplary. The villagers have conserved agricultural lands by adapting unique irrigation system(Da Costa, 1956). Curtorim village is blessed with six large lakes and River Zuari which depicts the fresh and saline water ecosystem. The ancestors of the village used and practiced the water management methods for agriculture and pisciculture, which is highlighting the age old aqua agri engineering system. The captive zone of water is regulated by bousces (association of cultivators who have to perform their duties properly). Traditional, Khazan technology has been used till date to protect agricultural fields and villages from tidal influx through a system of bunds (dykes) and salinity regulation. Estuaries, mangrove areas, outer and inner embankments, backwaters, creeks, sluice gates, and drainage canal form the important components of the khazan system. Village has Self governing institutions called as (Gaunkari /Comuninade) for conservation of Khazan ecosystems.Long before the Portuguese rule, traditional communities in Goa formed guilds for management of resources. The foundation of Gaunkari institution was based on the collective management of property and resources. During the Portuguese rule in Goa (1510-1961) they were renamed as comunidades.

Comunidades maintained the khazan ecosystem through 'bhaus' system (association of farmers). Resource management strategies using scientific approaches and community participation in this village help to enhance production without compromising the resource base. The resources of village are proposed to be conserved by declaring it as heritage site as is a living example of the native people who have very successfully interacted and understood the natural systems. This enabled them to create and maintain water harvesting technique based on engineering and topography, resulting in the unique systems of Khazan Management in the form of bunds and sluice gates. The bunds (inner and outer) act as anti erosive barriers and also regulate the circulation of river water or monsoon water. Thus during the monsoons, heavy rains washes out the salinity to support paddy cultivation while in the post monsoon sluice gates open and devoted for pisciculture thus showing a perfect agro-pisciculture ecology is still practiced in this village. Upland region of this heritage site is a classic example of Agro-pisciculture ecology of fresh water. Ralloitollem (lake) being a depression collects voluminous water through monsoonal precipitation and surface run off. This accumulated water is engineered for paddy cultivation. The Ralloitollem (lake) also serves for Agropisciculture giving post and pre monsoonal season. The famous 'Xhitto' (salinity resistant) rice variety is grown in this region along with other varieties like patni(white and red),kendall, bedo, babri, damgo, jyoti, jaya, azgo, etc.

For centuries, the people in this village have maintained this heritage, which reflects a mosaic of natural, semi- natural and man-made habitats, supporting significant diversity of life forms. Villagers have protected this rich, unique, ecologically fragile ecosystem under the laws of Biodiversity Heritage Site (BHS) for the management and conservation under sub section (2) of Section 37. Apart from the age old practices the PBR documentation of this village shows more than 165 varieties of plant species around 250 varieties of birds, 20 different mammals, 16 species reptile, 5 different types of amphibians while the aquatic habitat shows variety of macrophytes and phytoplanktons.

\section{Access and Benefit sharing}

This cultural site is living museum wherein the students of sociology, history, anthropology and planning, 
architecture and social geography can understand the human perspective at length. The students of life sciences get an opportunity to understand ecosystems, biodiversity, evolution and interdependence with regard to complex food web structures among the organisms. Curtorim as a village represents some of the traditional knowledge and ethos of Goa through agricultural practices, cultural monuments, feasts and other celebrations. As far as tourism is concerned the site is a mosaic of histo-socio- cultural and natural habitat. Each of these components can be showcased or explored for tourism development. The cultural tourism can emphasize on appreciating monuments, the architecture and historical records. Apart from these tourists would also get an opportunity to witness age old brew "Fenny making and their traditional Pao (bread making) bakery.

St. Alex church is a testimony of historical past and Portuguese legacy. Lakes are lifelines of Curtorim, as these water bodies are the representation of agro-pisci culture and ecosystem thus, enabling to derive economic and natural benefits.

\section{Success story}

Once Curtorim was known as granary of Salcette (larger part of district) (CVP 2020). During the process of documentation it was noticed that villagers used to cultivate varieties of rice following traditional cultivation practices. Specific variety was used for making special dishes. With introduction of high yielding varieties these traditional rice varieties having unique gene pool have disappeared and their names have also vanished over a period of time. Outcome of PBR documentation and validation process was the need expressed by local BMC of Curtorim to take up pilot scale commercial activity to promote Patni rice. This rice is cultivated in the kher (midlands) lands in kharif season.In this regard, GSBB took special initiative led by BMC Curtorim by involving local voluntary organization and farmers who have successfully branded and sold local rice under brand "Cuddtari". This has encouraged local farmers to conserve the germplasm of traditionally grown crops. Due to BMC initiatives, land under paddy cultivation has increased considerably.

\section{CONCLUSION}

To reiterate, this exercise of documentation in itself is an important boost to the whole stock of knowledge residing today with the villagers. Another best part of PBR is due credit is given to the individuals/ communities/ panchayats making available such information and is supplemented the with legal provisions to properly direct the sharing of benefits. PBR also helps in planning of management of bioresources. Curtorim village is rich in traditional knowledge, technology regulating Khazans, formation of self-governing institutions for management of resources. The PBR has documented biological resources, monuments, houses, cultural practices, festivals associated with conservation of water, harvest and thanks giving festival etc. and age-old resource management practices followed by the local people in the villagePBR has also helped in recording rare and endangered plants cataloged in the IUCN red data list as reported in PBR of Curtorim Village. It is only because of $\mathrm{PBR}$, the rice variety Patni grown by locals, in association of GSBB is promoted and branded as Cuddtaririce. People's Biodiversity Register proved to be a projection to fill the gap between knowledge \& ignorance. The access and benefits (ABS) are shared by the students, locals and tourists. PBR process is continuous and is certainly a tool of regional as well as national development with the practical involvement of rural people. With the help of GSBB the steps are taken towards conservation of documented bio resources of the village with participatory approach of local people.

\section{ACKNOWLEDGEMENT}

I would like to thank Member secretary of Goa State Biodiversity Board Dr. Pradip Sarmokadam. Chairperson of Curtorim BMC Mr. Santan Rodrigues and the members of Curtorim BMC deserve my sincere gratitude for their immense support.

\section{REFERENCES}

Azavedo, G. 2015.Curtorim celebrates its feast of fields and food. https:// timesofindia.indiatimes.com/ city/goa/Curtorim.

Da Costa, S. 1956.SupplementoCommemorativo Do Terceiroaniversárioda fundação de "Diário de Goa”, dedicado a fregusia de Curtorim- A wayForward, Herald Goa.

Reid, W. \&Mooney, H. 2005. Millennium Ecosystem Assessment:Ecosystems and Human well being synthesis. Island Press.

Rubinoff, J. 2001. Pink Gold: transformation of Backwater Aquaculture on Goa's Khazan lands. Economic and Political weekly.

Curtorim Village Panchayat-CVPwebsite URL - http:// www.curtorimpanchayat.com/curtorim-village/1

Rautaray O. P. et al. 2014.People's Biodiversity Register [PBR]: A CommunityBased New Venture in Odisha to document natural resources Env and Ecol Res 2(8): 285-290.

Vitousek, P. M.et al. 1997. Human alteration of the global nitrogen cycle: sources and consequences. Ecol Appl. 7(3)737-750.

Fernandes, G. 2016. Agrobiodiversity in Curtorim-A way forward. Herald Goa.

Wake, D. B.and Vredenburg, V. T. 2008. Are we in the midst of the sixth mass extinction? A view from the world of amphibians. The National Academy of Sciences of the USA. (105) 11466-11473.

http:/www.mpsbb.nic.in/pbr/PBR\%20Manual\%20and\% 20Format\%20-\%20English.pdf

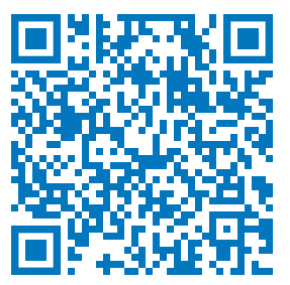

